\title{
Portraying the Multitudes: Representation of Identities of Sexual Minorities on Indonesia-Based Feminist Web Magazine Magdalene.co
}

Puji Maharani, SOAS, University of London

\begin{abstract}
This paper aims to examine the representation of identities of sexual minorities known as the LGBTQ (Lesbian, Gay, Bisexual, Transgender, Queer) community, on the Indonesiabased, feminist web magazine, Magdalene.co. This magazine provides a guide to women's issues while engaging with fresh perspectives beyond traditional gender and cultural confines. The representation of sexual minorities is reviewed through a selection of six published articles written by editorial members and third-party contributors' submissions. These submissions vary in age, gender, self-identification as sexual minorities and in anonyminity. The articles are examined through discourse analysis, primarily based on the discourse theory developed by Ernesto Laclau and Chantal Mouffe. ${ }^{1}$ Also incorporated into the analysis are Adrienne Rich's ${ }^{2}$ theory of how the politics of location effects how society looks at the bodies of sexual minorities and Gilbert Herdt's ${ }^{3}$ (2009) concept of sexual panic, to look at the increasing religious-conservatism in Indonesia in contrast to the sexuality of sexual minorities. This research examines the ways in which the representation of sexual minorities in the media opens a space of resistance against heteronormative public discourse.
\end{abstract}

Keywords: Sexual Minorities, Gender, Magazine, Public Discourse

\section{INTRODUCTION}

In mid-January 2016, a controversy provoked heated, public discourse on the identities of sexual minorities in Indonesia. The dispute started with the launch of a collaborative initiative for an LGBTQ Peer Support Network by Melela.org and the Sexuality Group and Resource Centre at the University of Indonesia (SGRC UI). The Peer Support Network, independently organized by UI students, was met

1 Ernesto Laclau and Chantal Mouffe, Hegemony and Socialist Strategy. Towards a Radical Democratic Politics (London: Verso, 1985).

2 Adrienne Rich "Notes towards a Politics of Location" in Adrienne Rich, Blood, Bread, and Poetry: Selected Prose 1979-1985 (London: Little Brown \& Co, 1984) 210-231.

3 Gilbert Herdt "Moral Panics, Sexual Rights, and Cultural Anger" in Gilbert Herdt, ed, Moral Panics, Sex Panics (New York: New York University Press, 2009). 
with sensationalised media exposure that was published under provocative tags such as "LGBT attacks campus."

News reports included claims that sexual minorities could convert heterosexuals into homosexuals. These reports claimed that this conversion makes the LGBTQ community a threat to children and youth ${ }^{5}$ in accordance with a hidden agenda to propagandise homosexuality in an academic setting. ${ }^{6}$ After the release of the news reports, prominent community figures and public officials gave their uninformed opinions which were based on their personal misunderstandings and biases. These controversial statements and the news coverage further marginalised sexual minorities, an already vulnerable group. ${ }^{7}$

In addition to these statements and new resportings, the dispute appears to use inaccurate language; the term "LGBTQ" becomes synonymous with "gay men." The generalization of the acronym "LGBTQ" allows for the exclusion of other marginalised groups such as the transgender community, lesbian women, and intersex people. ${ }^{8}$ In addition, most of the conversations in this debate left out Melela.org, SGRC UI's partner for the initiative. While SGRC was heavily scrutinised by the media exposure, Melela.org was mostly mentioned in passing. ${ }^{9}$ Only two news articles quoted an interview with Rio Damar, founder of Melela.org, and both were published by national newspaper The Jakarta Post.

These claims and the media discourse on sexual minorities inspired this research for two reasons. First, there is the psychological proximity from belonging to the same country. ${ }^{10}$ Secondly, there is an interest in examining the LGBTQ community from the perspective of a non-homosexual, non-transgender woman, who is motivated to study the lived experiences of those in the community. ${ }^{11}$

These personal interests encouraged the search for possibilities of an alternative discourse which could present the LGBTQ community in a different light. Already, Indonesian media varys in their coverage of LGBTQ issues,

4 “Topik terhangat: \#Lgbt Serang Kampus [Hot topic: LGBT Attacks Campuses]," Republika (accessed $15 \quad$ August 2016), online: http://www.republika.co.id/indeks/hot_topic/lgbt\%20serang\%20kampus.

5 Mario Rustan, 'The LGBT Scare and Indonesia's Culture War", Magdalene.co (7 March 2016), online: $\quad$ http://www.magdalene.co/news-722-the-lgbt-scare-and-indonesia\%E2\%80\%99s-culturewar.html.

6 Ayunda Nurvitasari, "SGRC UI Offers Help for LGBT Youth Going Through Hard Time", Magdalene.co (25 January 2016), online: http://www.magdalene.co/news-684-sgrc-ui-offers-helpfor-lgbt-youth-going-through-hard-time.html.

7 See ibid.

8 See Rustan, supra note 5.

9 From Google News search result per 16 August 2016, with specified time range from January to August 2016, keyword "SGRC UI" shows 190 news articles, while "melela.org" only 30.

10 Nira Yuval-Davis, The Politics of Belonging: Intersectional Contestations (Los Angeles and London: Sage, 2011) 94.

11 Sharyn Graham Davies Gender Diversity in Indonesia: Sexuality, Islam and Queer Selves (Abingdon and New York: Routledge, 2010) 8. 
ranging from supportive to hostile ${ }^{12}$ (UNDP and USAID 2014: 9). In response to the recent debate on sexual minorities, the general hostility continues. For example, the Indonesian Broadcasting Commission (KPI) established restrictions towards the promotion of activities of the LGBTQ community as part of an effort to protect children and teenagers from exposure to the community's lifestyle. ${ }^{13}$ This is only one instance of heteronormative gender biases which publicly promotes the ideals of the "real man" and the "real women" in the media; thus, there is a continuation of marginalisation of sexual minorities.

This is where Magdalene.co comes into play. Magdalene.co is an online media start-up based in Jakarta, Indonesia, that aims to offer alternative views to contrast the conventional gender and cultural mores. ${ }^{14}$ Co-founded by Devi Asmarani (Chief Editor), Hera Diani (Managing Editor), and Karima Anjani, the publication was launched on September 26, 2013. ${ }^{15}$ Apart from Diani's 11-part series 38 and Pregnant, no other editorial members publicly disclose their sexuality on the publication. However, through several of their articles, Magdalene.co's editorial team seems to have taken the subject position, or "extant social categories of selfhood," 16 of a "fag hag," or heterosexual woman, who befriends or becomes an ally for sexual minorities.

Being a new start-up, Magdalene.co is neither one of those online publications which are the extension of pre-existing print media nor part of any bigger media conglomerate group, many of which would use their media outlets as a means for their political interests. ${ }^{17}$ For those reasons, Magdalene.co has a considerably smaller niche of readership, but, therefore, has more freedom to determine which causes to promote in their publication.

This paper aims to examine the representation of the identities of sexual minorities in the media as a form of resistance against heteronormative public discourse. In particular, the paper focuses on Magdalene.co and how this particular media outlet endorses multitudes on its publication. The discussion is conducted in three parts.

12 UNDP and UNAIDS, Being LGBT in Asia: Indonesia Country Report, Bangkok (2014) 9.

13 Fedina S. Sundaryani, "Commission wants TV, radio free of LGBT" The Jakarta Post (14 February 2016), online: http://www.thejakartapost.com/news/2016/02/14/commission-wants-tvradio-free-lgbt.html.

14"Magdalene, A Slanted Guide to Women and Issues" Magdalene.co (undated), online: http://magdalene.co/static-1-aboutus.html.

15 Devi Asmarani, "First Year's a Charm: An Anniversary Note" Magdalene.co (13 November 2014), online: http://magdalene.co/news-278-first-year\%E2\%80\%99s-a-charm-an-anniversarynote.html.

16 Tom Boellstorff, The Gay Archipelago: Sexuality and Nation in Indonesia (Princeton: Princeton University Press, 2005).

17 Khrisna Sen and David T. Hill, eds, Politics and the Media in Twenty-First Century Indonesia: Decade of Democracy (London and New York: Routledge, 2010). 
The first part will look at sexual minorities discourse through the lens of hegemony and social antagonism. ${ }^{18}$ This lens will allow further examination of the LGBTQ's lived experiences by utilising the concept of politics of location ${ }^{19}$ and engaging with the concept of sexual panic ${ }^{20}$ in relation to social antagonism. Examinging the concept of sexual panic is important as sexual minorities are seen as challenging the heteronormative moral values. In this part, the intersection of religion and sexuality in its interplay with hegemony, which is enforced by heteronormativity, is highlighted.

The second part of this paper will elaborate deeper on the relationship between identities of sexual minorities and religious conservatism. First, the relationship is examined by looking at the problematic attempts to identify sexual minorities and how it is entwined with religious conservatism and sexual panics, which present the trouble of heteronormativity for sexual minorities in Indonesia. The analysis would underline religious conservatism and heteronormative oppression, which leave little room for sexual minorities to articulate their resistance in the media.

The third part will further examine the problems of heteronormative doublestandards in mainstream media discourse and the counter efforts of Magdalene.co's alternative discourse. Magdalene.co emphasises the need for new media as an enabler for sexual minorities to construct their own identities and articulate their resistance as the mainstream discourse marginalises the community

To conclude the study, the research incorporates the discussion on hegemony, sexuality, and religion to reflect on how representing the LGTBQ community's identities on Magdalene.co becomes a means for Indonesian sexual minorities to resist social antagonism that is sparked by sexual panics, which is fuelled by the rise of religious conservatism.

\section{INTRODUCING THE MULTITUDES: A THEORETICAL OVERVIEW}

\section{Sexual Minorities in the Discourse of Hegemony and Social Antagonism}

Representation of identities in relation to non-normative sexuality is an intriguing interplay. As one of the primary battle grounds for the rights of sexual minorities and the establishment, representation constitutes status to non-normative identities; ${ }^{21}$ the term "identities" is defined as a publicly articulated self-image and

18 See Laclau \& Mouffe, supra note 1.

19 See Rich, supra note 2.

20 See Herdt, supra note 3.

21 Ian Rivers \& Richard Ward, Out of the Ordinary: Representations of LGBT Lives (Newcastleupon-Tyne: Cambridge Scholars Publishing, 2012) 2. 
perceived sense of self. ${ }^{22}$ Therefore, to discuss representation of identities of sexual minorities on online media, given its battlefield nature, is to not only look at the study of gender, sexuality, and media but also to analyse the intersection as a discourse of conflict in the society.

Conflict, not harmony, often becomes the main character to present the fundamental state of society; and, societal conflict has a critical role in assembling the identity of hegemonic discourses through the notion of social antagonism, in which friend-foe division is constituted. ${ }^{23}$ As discourse is constructed with the expulsion of other potential meanings or "radical otherness," ${ }^{24}$ heteronormativity, or the values, norms, and systems associated to heterosexuality, ${ }^{25}$ rises as an indispensable concept in discourse formulation. This construction consequently creates the exclusion, or "othering," of sexual minorities.

Noting that hegemony is a concept of the political construction of identity which formulates values and beliefs as its inseparable part, ${ }^{26}$ the representation of identities of sexual minorities mutually conditions discourse and hegemony. Hegemonic practice forms and reforms discourse and leads to a chance hegemonic articulation. ${ }^{27}$ Torfing $^{28}$ calls this practice social antagonisms. A social antagonism occurs when contrasting identities mutually exclude one another and discourses clash; ${ }^{29}$ and, any social relation constructed as subordinate, or any collective subject whose constructed subjectivity to particular existing discourse is negated by other discourses, can be in a position of antagonism which initiates conflict. $^{30}$ Social antagonism is a "double-edged sword" that develops social identity by assuming a danger to it. ${ }^{31}$ As seen in the case of sexual minorities, the negation of their identities due to social antagonism puts the community in a vulnerable position that is prone to structural violence.

However, the concepts of discourse, hegemony, and social antagonism can be versatile tools for empirical research concerning identity and conflict analysis. This is seen in the works of Ernesto Laclau and Chantal Mouffe, ${ }^{32}$ in which they redefine the idea of hegemony to include "the articulation of social identities in

22 See Davies, supra note 11, page 13.

23 Jacob Torfing, New Theories of Discourse: Laclau, Mouffe, and Zizek (Oxford and Malden: Blackwell, 1999) 82.

24 Marianne W. Jørgensen \& Louise Phillips, Discourse Analysis as Theory and Method (London, Thousand Oaks, and New Delhi: SAGE Publications Ltd., 2002) 56.

25 See Davies, supra note 11, page 13.

26 See Torfing, supra note 23.

27 See Torfing, supra note 23, page 43.

28 ibid.

29 See Jørgensen \& Phillips, supra note 24, page 47-48.

30 Chantal Mouffe "Hegemony and New Political Subjects: Towards a new concept of democracy" in James Martin, ed, Chantal Mouffe: Hegemony, radical democracy, and the political New York: Routledge, 2013 (1988)) 47, 51.

31 See Torfing, supra note 23, page 131.

32 See Jørgensen \& Phillips, supra note 24, page 49-50. 
the context of social antagonism. ${ }^{33}$ Mouffe ${ }^{34}$ also emphasises that the articulation of resistance against domination depends on the discourse and power relations in the on-going struggle for hegemony.

In Laclau and Mouffe's discourse theory, individuals and groups are understood as "subject positions determined by discourse." ${ }^{35}$ The formulation of subject positions, and thus identities, is defined as a site of struggle where contrasting arrangements of elements endeavour to conquer. ${ }^{36}$ Moreover, the identity of multitudes of subject positions depends on the articulation of identification. ${ }^{37}$

As articulation becomes a practice that constitutes a mutually fundamental relationship between social, political, and cultural elements, ${ }^{38}$ mass media has a definitive social, political, and cultural significance. ${ }^{39}$ However, above everything, mass media is a site of the battlefield over identity, distribution, and societal control. $^{40}$ The antagonistic relation between political groups and social classes is indispensable in revealing how power relations and resistance are formed in and through mass media. Both are conditional on the articulation of meaningful orders and the promulgation of these within society. ${ }^{41}$

Mass media supports the establishment and maintenance of hegemony of particular political groups, but they also supply the medium and substances for resistance and counter-hegemonic struggles. There is an abundant multitude of voices and meanings to supply substance for the articulation of alternative meanings and political initiatives. ${ }^{42}$ Meanwhile, new technologies related to the media are often observed with rampant optimism, yet, at the same time, new media can also spark panic and fear. ${ }^{43}$

33 See Torfing, supra note 23, page 13.

34 See Mouffe, supra note 42, page 52.

35 See Jørgensen \& Phillips, supra note 24, page 55.

36 See Jørgensen \& Phillips, supra note 24, page 47.

37 Chantal Mouffe "Feminism, citizenship and radical democratic politics" in Chantal Mouffe and James Martin, ed, Chantal Mouffe: hegemony, radical democracy, and the political (London: Routledge, 2013) 134.

38 See Laclau \& Mouffe, supra note 1, page 105.

39 See Torfing, supra note 23, page 210.

40 Douglas Kellner, Media Culture Cultural Studies, Identity, and Politics Between the Modern and the Postmodern (London and New York: Routledge, 1995) 35, italics in original.

41 See Torfing, supra note 23, page 212.

42 See Torfing, supra note 23, page 210-211, 223.

43 Mia Consalvo, "Gender and New Media" in Bonnie J. Dow and Julia T. Wood, eds, The SAGE Handbook of Gender and Communication (London, Thousand Oaks, and New Delhi: SAGE Publications, Inc., 2006) 355-369. 


\section{Locating the Bodies of Sexual Minorities}

Rich $^{44}$ notes that to refer to one's own body is to start "with the material," to locate one's closest geographical site from which they articulate their lived experience with authority and reclaim it, while minimizing the temptation for generalisations. At the same time, there is acknowledgment that the body has multitude of identities. Moreover, locating the body goes beyond understanding what it means to have certain body parts which define one to be a male or a female; it is also about the conditions and limitations one has taken for granted. ${ }^{45}$ Our bodies are "the location of being" through which we experience and understand "the realities of worlds."

Within discourse, the body is observed from three points of view: the phenomenological body, where personal body experience begins; the social body, from which a symbolic system to think about nature, culture, and society is developed; and the body politic, as an object that can be socially or politically controlled. ${ }^{48}$ The (material) body becomes the medium from which the body politic rules what types of bodies, sex, gender, and sexuality are constituted as "normal" and legitimate and what identities are regarded as appropriate. ${ }^{49}$

The notion of legitimate bodies and appropriate identities is the essence of the discussion on sexual minorities, as heteronormativity brings them a unique challenge to embrace their body as the primary site of their sexuality. While Rich speaks about women, her thoughts echo the lived experience of sexual minorities, as they are not excluded from "a tangle of oppression" from being the discursive of heteronormative discourse, thus most of them must struggle for their lives on many battlefields at once. ${ }^{50}$

Rich is seconded by Davies, ${ }^{51}$ who observes that Indonesia is no stranger to using genitalia as a clear and permanent definition of a male or female body, which determines one's notion of self and the aspects of social life. Genitalia is also considered inseparable from the notion of shame which powerfully regulates sexuality. ${ }^{52}$ The Indonesian word for genitalia is kemaluan from the root word

44 See Rich, supra note 2, page 215.

45 See Rich, supra note 2, page 215-216, 219.

46 Jason Cromwell, Transmen and FTMs: Identities, Bodies, Genders, and Sexualities (Champaign: University of Illinois Press, 1999) 32

47 Susan DiGiacomo, "Metaphor as illness: Postmodern dilemmas in the representation of body, mind and disorder" in Medical Anthropology Volume 14 Issue 1, 1992, 114.

48 Nancy Scheper-Hughes and Margaret M. Lock, "The Mindful Body: A Prolegomenon to Future Work in Medical Anthropology"'in Medical Anthropology Quarterly, New Series, Vol. 1, No. 1, 1987, 7-8.

49 See Cromwell, supra note 46.

50 See Cromwell, supra note 46, page 218.

51 See Davies, supra note 11, page 20.

52 Sharyn Graham Davies \& Linda Rae Bennet "Introduction: mapping sex and sexualities in contemporary Indonesia" in Linda Rae Bennet and Sharyn Graham Davies, eds, Sex and sexualities in contemporary Indonesia (London: Routledge, 2015) 13. 
malu (shame). ${ }^{53}$ Sexual minorities in Indonesia cannot escape the compelling notion of shame in relation to their sexuality especially due to heteronormative angle of observing bodies which they do not conform into in the first place. Therefore, this notion of shame influences the way the LGBTQ community members locate and reclaim their bodies to articulate their identities.

Meanwhile, heteronormative attempts to render bodies as unambiguously male or female ${ }^{54}$ may lead to physical alteration of bodies to create congruence with one's identity. ${ }^{55}$ While the possibility is there, especially for transgender people, these physical alterations may be a conflicting move particularly when religious perspective of observing bodies is incorporated. For example, Islam allows khunsa (intersex) to undergo a sex-change surgery, but that does not apply to mukhannis or mukhannas (males who dress up and behave like females or vice versa). ${ }^{56}$

With all these complications surrounding the (material) bodies of sexual minorities, the absence of the material body on the internet may appear to be a liberating beginning to the use of new media, in which an abridged version of one's lived experience formulates their identities. According to Paasonen, the liberty to be bodiless online is similar to trying on various kind of masks or personas rather than creating entirely new, alternate identities ${ }^{57}$.

While some theorists such as Turkle and Stone argue that new media offers the possibility to be an arena for identity play and experimentation, others like Nakamura and Paasonen believe that online exploration of gender and race frequently leads to the repetition of stereotypes familiar in other places. ${ }^{58}$ The use of online pseudonyms to represent the identities of sexual minorities, done by both the contributors of Magdalene.co who identify as sexual minorities themselves as well as the publication's editorial team on their advice column, is one example of this identity experiment. What matters more than their material bodies as their primary location is the (offline) lived experience of their bodies and how they choose to represent their identities from that site to articulate their resistance online.

53 Sharyn Graham Davies, "Surveilling sexuality in Indonesia" in Linda Rae Bennet \& Sharyn Graham Davies, eds, Sex and sexualities in contemporary Indonesia (London: Routledge, 2015) 33.

54 Anne Fausto-Sterling, Sexing the Body: Gender Politics and the Construction of Sexuality (New York: Basic Books, 2000).

55 See Cromwell, supra note 46, page 29-30.

56 Yik Koon Teh "Politics and Islam Factors Determining Identity and the Status of Male-toFemale Transsexuals in Malaysia" in Fran Martin \& Peter A. Jackson, eds., AsiaPacifiQueer: Rethinking Genders and Sexualities (Baltimore, US: University of Illinois Press, 2008, pp. 85-98) 57 See Consalvo, supra note 43, page 358.

58 ibid. 


\section{Sexual Minorities in the Midst of Sexual Panic}

Observing the controversy against sexual minority which inspired this study constantly brings one word to mind: panic. Herdt, ${ }^{59}$ through his analysis of Stanley Cohen's 60 concept of moral panics, calls such controversy "sexual panics." Panic, he says, is the degree to which the personal and societal articulation are out of proportion with the actual danger asserted by the scapegoated individuals, groups, or issues, or "folk devils", producing stigma, rejection, and social exclusion. $^{61}$

Herdt's concept of sexual panics was initially coined as "sex panic" by Carole Vance in 1984, which reflects a type of moral panic that constructs public conflict based on sexuality and sexual morality. ${ }^{62}$ As a form of moral panic, sexual panics sexualises these "folk devils" as "monsters" and "predators," 63 as seen through how, in the analysis in this study, "gay" becomes the umbrella term for sexual minorities while being mixed up with paedophilia and considered as a sinful, contagious threat. ${ }^{64}$ This paper will continue to use the term "folk devils" to refer to sexual minorities to stay in line with the title of Cohen's seminal work, Folk Devils and Moral Panics.

In revealing the ideologies, hierarchies, and social gaps of societies, moral panics are at its most detrimental in the propagation of sex and gender differences. ${ }^{65}$ Sexualised moral panics "have much in common with religious disputes of earlier centuries," yet the present surge of "neoconservatives" and "religious fundamentalism" is inseparable from sexual panics. ${ }^{66}$ This surge is relatable to the rise of religious-conservatism in Indonesia. Today, sexual panics can be seen as one of the most decisive mechanisms that reproduce structural violence through the embodiment of "fear, disgust, and social exclusion" in meanings, speech, and actions. ${ }^{67}$

On one hand, media representation plays a pivotal role in inflaming public arguments against sexual minorities as folk devils. The emotional hostility in public settings embodies the energy in which sexual panics thrive, ${ }^{68}$ as the exaggerated fear for moral decay disperses through the media into everyday speech and habits. ${ }^{69}$ Irvine $^{70}$ uses the term "sex panic scripts" to describe such

59 See Herdt, supra note 3.

60 Stanley Cohen, Folk Devils and Moral Panics: The Creation of the Mods and Rockers (London: MacGibbon \& Kee, 1972)

61 See Herdt, supra note 3, page 1-3.

62 Janice M. Irvine, "Transient Feelings: Sex Panics and the Politics of Emotions" in Gilbert, Herdt, ed, Moral Panics, Sex Panics (New York: New York University Press, 2009) 238-239.

63 See Herdt, supra note 3, page 1, 5, 7, 10.

64 See Rustan, supra note 5.

65 See Herdt, supra note 3, page 18.

66 See Herdt, supra note 3, page 1-2.

67 See Herdt, supra note 3, page 18.

68 See Irvine, supra note 62, page 244.

69 See Herdt, supra note 3, page 13. 
passionate ways of speech that suggest the creation of emotional publics as a factor of panics. Sex panic scripts largely rely on the "danger and disease" sexual groups or issues associated with "highly stigmatised forms of sexuality.",72 These scripts use provocative language and narratives of immorality to present distorted, hyperbolised, or fabricated stories $^{73}$ and can be easily found in "sensationalist"

In a religious-conservative perspective, the moral legitimacy of collective panics suggests individual response to sex panic scripts based on profound religious predispositions; yet, this can exaggerate sexual panics. ${ }^{75}$ Meanwhile, individual resistance against sex panic scripts, as an act of subversion within the dominance of binaries, ${ }^{76}$ is challenging, because even that very act is stigmatised and ignored. $^{77}$

These compelling sexual panics produce images of the sexual scapegoats as monstrous enemies in a process of "othering." This act of "othering" dehumanises and strips the folk devils of their rights ${ }^{78}$ which can be observed through media representations, as the media orchestrates and purposefully disperses fearful ideas and imagery. ${ }^{79}$ However, media can also play the role in the other end of the spectrum, and Magdalene.co has made it possible.

\section{IDENTITIES OF SEXUAL MINORITIES AND RELIGIOUS CONSERVATISM}

\section{Sexual Minorities as a Folk Devil for Social Antagonism}

Normative representations of everyday living begin with binaries which construct our understanding of social relations. ${ }^{80}$ These binaries are challenged the moment one leads a "non-normative" life, which starts with the need for transition or desire to be outside of gender confines, as heteronormative gender is defined by sexual behaviour. $^{81}$

Despite the common, ingrained premise that heterosexuality represents goodness and purity, ${ }^{82}$ homosexuality may only pose an actual threat when sexual-minority activities are incorporated into an unwelcomed alternative way of

70 See Irvine, supra note 62, page 253.

71 See ibid.

72 See Irvine, supra note 62, page 255.

73 See Irvine, supra note 62, page 253.

74 See Irvine, supra note 62, page 244.

75 See Irvine, supra note 62, page 260.

76 See Cromwell, supra note 46, page 17.

77 See Irvine, supra note 62, page 257.

78 See Herdt, supra note 3, page 3.

79 See Herdt, supra note 3.

80 See Rivers \& Ward, supra note 21, page 3.

81 See ibid, see also Boellstorff, supra note 16

82 See Rivers \& Ward, supra note 21, page 4. 
life in the society. ${ }^{83}$ Such challenges show "otherness," which oftentimes is also seen as a deviance- fluid and socially produced instead of being a natural subordinate to a dominant definition of normal self ${ }^{84}$.

Fluidity has been a character of gender systems in Southeast Asian countries historically, but modernity introduced the binaries of sex and gender and the changes stayed. ${ }^{85}$ Interestingly, deviance from heterosexuality today is widely identified as a "Western disease" of a sexually liberal and morally confused society $^{86}$, an undesirable and out of place import which symbolises Western globalisation and opposes traditional "Asian values" (Baird 2007: 16, 92). In Indonesia, heterosexism, or the assumed superiority of heterosexuality to other sexualities, historically does not imply homophobia or the psychologised antagonism or apprehension of non-normative sexualities; thus, oftenthere is misrecognition of "Indonesian culture" in relation to the tolerance of homosexuality ${ }^{88}$ (Boellstorff 2005a: 223).

Sharing one's lived experience as sexual minority would require public declaration of sexual identity. In the West, openly acknowledging and disclosing one's own same-sex desires is called "coming out" 89 of the closet, a symbol of oppression of sexual minorities who have been silenced from articulating their sexual identity ${ }^{90}$. Publicly identifying as a sexual minority can be interpreted as liberation from heteronormative gender binaries, as Magdalene.co's contributor Paramita Mohamad ${ }^{91}$ (2014), who is openly lesbian, succinctly put:

"If you are still hiding in the closet, you continuously have to secondguess what others know about you, and what will happen if they do. This sucks a lot of contentment and mental energy out of you."

83 Vanessa Baird, No-Nonsense Guide to Sexual Diversity (Oxford: New Internationalist Publications, 2007) 91.

84 Caroline Ramazanoglu \& Janet Holland, Feminist Methodology: Challenges and Choices (London: SAGE Publications Ltd., 2002) 108, see also Irvine, supra note 62, page 239.

85 Michael Peletz, Gender Pluralism: Southeast Asia since Early Modern Times (New York, NY: Routledge, 2009).

86 Andrew K. T. Yip and Amna Khalid, "Looking for Allah: Spiritual Quests of Queer Muslims" in Kath Browne, Sally R. Munt, and Andrew K. T. Yip, Queer Spiritual Spaces: Sexuality and Sacred Places (Farnham: Routledge, 2010) 82-83.

87 See Baird, supra note 83, page 16 and 92.

88 See Boellstorff, supra note 16, page 223.

89 Robert A. Rhoads, Coming Out in College: The Struggle for a Queer Identity (Westport: Bergin \& Garvey, 1994), page 7.

90 See ibid, page 76 .

91 Paramita Mohamad, "Of Cats and Women: Resisting Lesbian Clichés", Magdalene.co (16 January 2014), online: http://www.magdalene.co/news-80-of-cats-and-women-resisting-the-lesbianclich\%C3\%A9s.html. 
Magdalene.co's editorial team, under the pseudonym of Madge on the website's Ask Madge advice column ${ }^{92}$, seconds Mohamad's view in resposne to an inquiry on coming out to parents. Taking reference from her own experience as a "hag", or a confidant for her gay friends, Madge claims that the decision to come out is not something a pesron will regret.

However, the notion of sexual minority identities is not universal. It is common for people to engage in same-sex activities, or 'do homosexuality,' without identifying themselves as homosexuals ${ }^{93}$. This way, same-sex desires do not necessarily produce a culturally acknowledged, social identity ${ }^{94}$. Boellstorff's ${ }^{95}$ ${ }^{96}$ research on Indonesian gay men and lesbian women points out that many gay men marry women and put their lives into the compartments of a "normal world" and a "gay world." These men and women are able to compartmentalize without having the feeling of contradition ${ }^{97}$ or being untrue to their sexuality. Nevertheless, as Indonesian gay men and lesbian women try to bring their two worlds together into a "failed" intersection, they articulate that they do feel as if they live a "double life" " "My semi-closeted life has led me to encounter some gay Muslims who end up becoming the most homophobic characters just for the sake of appearing straight."

From Magdalene.co's contributor Downtown Boy's ${ }^{99}$ poignant description, the impact of domineering heteronormative discourse coincides with the Muslim culture in Indonesia, particularly that the matter of identifying oneself as sexual minority is clearly a thorny one. ${ }^{100}$ Despite tolerant attitude on sexual minorities from a few Muslim intellectuals in the past decade, presently it is impossible to be publicly gay and considered a devout Muslim ${ }^{101}$. However, the remainder of Downtown Boy's piece resonates with scholars ${ }^{102}$ who believe that, despite the

92 Magdalene “Ask Madge: Coming Out to Parents" Magdalene.co (11 May 2015), online: http://www.magdalene.co/news-384-coming-out-to-parents.html.

93 See Baird, supra note 83, page 17.

94 See Davies, supra note 11, page 208.

95 See Boellstorff, supra note 16.

96 Tom Boellstorff, "Between Religion and Desire: Being Muslim and Gay in Indonesia" in American Anthropologist (107, no. 4, 2005) 575-585.

97 Tom Boellstorff, "Zines and Zones of Desire: Mass-Mediated Love, National Romance, and Sexual Citizenship in Gay Indonesia" in The Journal of Asian Studies (63, no. 2, 2004) 367402.

98 See Boellstorff, supra note 16, page 14.

99 Downtown Boy (pseudonym), "Muslim and Gay: 10 Facts You May Not Know About Us" Magdalene.co (16 January 2014) online: http://www.magdalene.co/news-82-muslim-and-gay\%E2\%80\%93-10-facts-you-may-not-know-about-us.html.

100 Rusmir Musić, "Queer Visions of Islam" in Samar Habib, ed, Islam and Homosexuality (Westport: Praeger, 2009) 327-345.

101 See Boellstorff, supra note 96, page 582.

102 Melissa M. Wilcox, "Outlaws or In-Laws? Queer Theory, LGBT Studies, and Religious Studies" in Karen E. Lovaas, John P. Elia, and Gust A. Yep, eds, LGBT Studies and Queer 
struggle, sexual minority identities can harmonise with almost any religious belief and practice. This is done through the individual process of identity negotiation. However, some members of the LGBTQ community would find their religion to be discouraging thus creating the feeling of needing to choose between identifying as a sexual minority and being religious.

In the Indonesian context, the "coming out" metaphor, used in many EuroAmerican sexual minority communities, usually only refers to participation in the gay world. ${ }^{103}$ A small number of Indonesian sexual minorities would translate "coming out" as memproklamirkan diri (to proclaim oneself), a reference to the proclamation of Indonesia as an independent state, not as membuka diri (opening oneself). ${ }^{104}$

Nevertheless, the lack of recognition of Indonesian sexual minorities leads to the aspiration for social acceptance. This aspiration includes being spared from shaming due to their sexuality, the freedom from pressure to be heterosexually married, and the freedom to conduct same-gender activities in the "gay world" uninterrupted. ${ }^{105}$ The desire for recognition, unlike how it is understood by Western sexual minority movements, rarely takes the form of political aspirations, such as to legalise same-sex relationship. This is because exclusive homosexuality as an alternative to traditional family norms is not something many Indonesian sexual minorities would endorse. ${ }^{106}$

Another point worth noting is the visibility of sexual minorities. Visibility is important because the sense of gender or sexual difference might be missing in everyday life due to lack of understanding of the lived experiences of sexual minorities or the failure to engage with issues related to them. ${ }^{107}$ However, both visibility and invisibility have costs which are not limited to clichés, prejudices, and stereotypes. The need for visibility emphasises the importance of coming out, ${ }^{108}$ but, as "the oxygen of equality," visibility can also be hazardous ${ }^{109}$ because "deviant identities" can sometimes be made visible only to be silenced later. ${ }^{110}$

Magdalene.co's columnist Mario Rustan ${ }^{111}$ addresses the issue of visibility through the experiences of the Indonesian female transgender community. The Indonesian transgender female, or waria (acronym from the Indonesian words wanita [women] and pria [men]), is incomparable in the West ${ }^{112}$ because it is

Theory: New Conflicts, Collaborations, and Contested Terrain (Binghamton: Harrington Park Press, 2013) 73-100.

103 See Boellstorff, supra note 97, page 376.

104 See ibid.

105 See Boellstorff, supra note 16, page 223.

106 See Boellstorff, supra note 16, page 223-224.

107 See Rivers \& Ward, supra note 21, page 132.

108 See Rhoads, supra note 89, page 174.

109 See Baird, supra note 83, page 8.

110 See Rivers \& Ward, supra note 21, page 133.

111 See Rustan, supra note 5.

112 See Boellstorff, supra note 16, page 11. 
translated as "inferiority" instead of "acceptance." 113 Recent homophobic attacks led to the closure of the only pesantren (Islamic school) for waria in the country which stripped the waria community of the right to practice their religion. This is is only one example of how transgender people are part of the sexual minorities who oftentimes suffer the most due to their public visibility.

The silencing of sexual minorities is inseparable from the negation of identity based on sexual morality. The silencing and negation of sexual minorities inflames social antagonism against folk devils in a sexual panic which takes place in an antagonistic environment. ${ }^{114}$

In this study, such act of exclusion, from the perspective of sexual minorities, reflects what Torfing ${ }^{15}$ calls a passive and traumatic incorporation of inadequacy. This reflection can be observed through the statements from the contributors of Magdalene.co under the pseudonyms of Downtown Boy, The Grand Dark Witch, and Sholeh Queer. However, Torfing ${ }^{116}$ also points out the possibility of "open confrontation" between the force of negation and the negated identity, which is built as a piece of an opposing conspiracy. Such possibility is present in Mario Rustan's analysis on the LGBTQ scare, ${ }^{117}$ Paramita Mohamad's resistance of lesbian clichés, ${ }^{118}$ Magdalene.co's news report on SGRC UI and young people from sexual minorities, ${ }^{119}$ and Madge's response to Sholeh Queer's inquiry on Magdalene.co's advice column Ask Madge. ${ }^{120}$

The case of Magdalene.co illustrates Sender's ${ }^{121}$ argument that new media genres and technologies enable opportunities for self-representations of sexual minorities in the first decade of the 2000s. This not only brings the chance for sexual minorities to articulate themselves instead of being spoken for but also creates an ideological investment to produce more accurate representations of the lived experiences of sexual minorities. These opportunities will help the community become more socially engaged. ${ }^{122}$ That said, contrary to Pullen's ${ }^{123}$ hopeful work, the articulation of the lived experiences of sexual minorities are not necessarily detached from histories of oppression, shame, or stigma; as, many

113 See Boellstorff, supra note 16, page 12.

114 See Torfing, supra note 23, page 120-121. See also Herdt, supra note 3.

115 See Torfing, supra note 23, page 120.

116 See Torfing, supra note 23

117 See Rustan, supra note 5.

118 See Mohamad, supra note 91.

119 See Nurvitasari, supra note 6.

120 See Magdalene, supra note 92.

121 Katherine Sender (2011) 'No Hard Feelings: Reflexivity and Queer Affect in the New Media Landscape' in Karen Ross, ed., The Handbook of Gender, Sex and Media (Chichester: Wiley-Blackwell, 2011) pp. 207-225.

122 See ibid.

123 Christopher Pullen, Gay Identity, New Storytelling and the Media (New York: Palgrave Macmillan, 2009) 22. 
sexual minorities in Indonesia live their lives in "compartments" 124 due to the possibility of being scrutinised as the folk devils of social antagonism.

\section{Religious Conservatism and Sexual Panics}

Southeast Asia has the reputation of being comparatively gender-liberal, and Islam in the region has a similar reputation of being moderate on the matters of gender orders compared to the Middle East or neighbouring South Asian countries. ${ }^{125}$ However, in the past two decades, the revival of a more conservative type of Islam has become apparent across the region, and these transnational Islam discourses are being adopted locally. ${ }^{126}$ This is also occuring in Indonesia, being the fourth most populous country and home to the largest Muslim population in the world. With approximately nine-tenth of around 230 million inhabitants whom follow Islam, ${ }^{127}$ there have been major changes after the authoritarian New Order regime fell in $1998 .^{128}$

Islam began to spread through Indonesia since the 13th century. ${ }^{129}$ In addition, the country's independence on the $17^{\text {th }}$ of August 1945 was inseparable from the prominent role and aspiration of Islamic organisations to build an Islamic state. However, Soekarno, the republic's first president, preferred a multireligious state in the name of national unity. ${ }^{130}$ This move sparked uproars from Muslim separatists which ended in military interventions and led to a repressive climate toward Islam and viewing Islamic behaviours under suspicious eye of political subversion for decades. This climate lasted until Soeharto, who succeeded Soekarno in 1966, started to seek political support from Muslim organisations in the 1980 s. ${ }^{131}$

Political, power-related discourses aside, many embraced Islam during Soeharto's New Order regime as a source of values to support the establishment of social equity, justice, and a new ethical compass during a fast-changing world. ${ }^{132}{ }^{133}$ Throughout the existence of the nation, Islamic influences and interpretations coexisted with people's other adherences and identities in

124 See footnote 110.

125 Susanne Schröter, ed, Gender and Islam in Southeast Asia: Women's Rights Movements, Religious Resurgence and Local Traditions (Leiden and Boston: Brill, 2013) 1, 7.

126 See ibid, page 1.

127 See Boellstorff, supra note 16, page 16.

128 See Schröter, supra note 125, page 2.

129 Hermanus J. de Graaf, "South-East Asian Islam to the Eighteenth Century", in P.M. Holt et al., eds, The Cambridge History of Islam Vol. $2 A$ (Cambridge: Cambridge University Press, 1970).

130 Kathryn Robinson, Gender, Islam and Democracy in Indonesia (Abingdon and New York: Routledge/Taylor \& Francis e-library, 2008). See also Robert W. Hefner, Civil Islam: Muslims and Democratization in Indonesia (Princeton: Princeton University Press. 2011).

131 See Schröter, supra note 125. See also Hefner, supra note 130.

132 See Robinson, supra note 130, page 167.

133 See Hefner, supra note 130, page 17. 
Indonesia. ${ }^{134}$ Islam has been used as both a justification to oppress non-normative subjects and to support gender diversity. ${ }^{135}$

The end of Soeharto's regime brought changes to the tolerant image of Indonesian Islam and Muslims. ${ }^{136}$ With the absence of the New Order's control on transnational Islamic currents and the presence of a democratic atmosphere in the country, "the genie of Islamism" is now out of the bottle. ${ }^{137}$ Islam found its public stage ${ }^{138}$ and subdued the influence of the moderate, mainstream thoughts of Muhammadiyah and Nahdlatul Ulama, the two largest Muslim organisations in Indonesia. $^{139}$

This new, public stage led to conservative Muslims calling for more restrictive laws on sexual morality. ${ }^{140}$ These restrictive laws object the notion of gender equality ${ }^{141}$ and support the struggle of Islamist groups to promote 'traditional' gender relations as a means to assert hegemony. ${ }^{142}$ However alarming, the recent rise of religious conservatism in Indonesia is part of a globally soaring degree of religious restriction in the world, as indicated by a Pew Forum study. ${ }^{143}$

Meanwhile, religion is a possible cause of sparking sexual panics, as it is increasingly enforced as a justification to discriminate against and stigmatise nonnormative gendered subjects ${ }^{144} 145$, whom they view as folk devils. Islam, possibly the most condemnatory and intolerant organised religion on matters of sexual diversity ${ }^{146}$, is seen to remain "violently hostile" to any non-heteronormative ways of articulating sexual desire. Nonheteronomative sexual desire is considered unnatural in Islam because it challenges the contradictory harmony of the sexes. ${ }^{147}$ In many antagonistic environments where hegemonic articulations

134 Rachel Rinaldo, Mobilizing Piety: Islam and Feminism in Indonesia (New York: Oxford University Press, 2013) 35.

135 See Davies, supra note 11, page 210.

136 Martin van Bruinessen, ed, Contemporary Developments in Indonesian Islam: Explaining the "Conservative Turn (Singapore: Institute of Southeast Asian Studies, 2013).

137 See Robinson, supra note 130, page 180.

138 See ibid, page 186.

139 See van Bruinessen, supra note 136, page 5.

140 Monika Arnez, "A Dialogue with God? Islam and Lesbian Relationships in Two Post-Suharto Narratives" in Susanne Schröter, ed, Gender and Islam in Southeast Asia: Women's Rights Movements, Religious Resurgence and Local Traditions (Leiden and Boston: Brill, 2013) 74.

141 See van Bruinessen, supra note 136, page 16.

142 See Robinson, supra note 136, page 165.

143 Hera Diani, "Religious Resurgence in Indonesia Alarming: Muslim Scholar" Magdalene.co (20 June 2016), online: http://www.magdalene.co/news-843-religious-resurgence-in-indonesiaalarming-muslim-scholar.html.

144 See Baird, supra note 83, page 96.

145 See Davies, supra note 11, page xv.

146 See Yip \& Khalid, supra note 86, page 82.

147 Abdelwahab Bouhdiba, (Alan Sheridan, trans.) Sexuality in Islam (Los Angeles: Saqi Books, 1998) 31. 
occur $^{148}$, such views stay to dominate the discourse even though it is not universally accepted among Muslims. ${ }^{149}$

For Muslims, antagonism of same-sex eroticism stems from the tale of Sodom which can lead to the interpretation of homosexuality as "unlawful" in Islam. ${ }^{150}$ This interpretation creates the image of incompatibility of Islam and homosexuality. ${ }^{151}$ Negative attitudes toward sexual diversity, as well as gender mainstreaming, is shared in a considerable part of the population along with plenty of religious leaders who perceive sexual diversity as a deterioration of Islamic values.

To call for a return to heteronormative gender ideals, the conservatives disseminate moral teachings using modern media. ${ }^{152}$ In a panic reaction responding to the accelerated pace of change, conservatives cherry-pick the "traditional values" "153, and their messages are clear: anything non-heterosexual is a sinful and contaminating 'Other ${ }^{154}$, thus victimising sexual minorities. ${ }^{155}$

\section{The Religious-Based Heteronormative Oppressions for Sexual Minorities}

Putting homosexuality and immorality in the same sentence is a recipe for heteronormative oppression that leads to problematic assumptions. These assumptions lead to the rejection of sexual minorities. One of the most oftenrecurring examples is the need to heal uncontrollable, 'abnormal' desires, in which heterosexual marriage becomes the only approved means to express one's sexuality. $\left.\left.{ }^{156}\right|^{157}\right|^{158}$ This singular means of expression is a result from masculine sexual privilege and the normative notion of heterosexual marriage. These ideas are housed in an intersection of kinship ties, respect of older relatives, the State's hegemonic opinions on women's 'duty to marry', and Islamic beliefs of the nature of men and women. ${ }^{159}{ }^{160}$ All of these factors are incorporated with kodrat (fate), nasib (destiny), and the idea of God's will. ${ }^{161}$

148 See Torfing, supra note 23, page 121.

149 See Boellstorff, supra note 96, page 576.

150 See Baird, supra note 83, page 101.

151 Samar Habib, ed, Islam and Homosexuality (Santa Barbara: Praeger, 2010).

152 See Schröter, supra note 125, page 39.

153 Dennis Altman, Global Sex (Chicago: University of Chicago Press, 2001).

154 See Yip \& Khalid, supra note 86, page 82.

155 See Baird, supra note 83, page 15.

156 See Bouhdiba, supra note 1.

157 See Boellstorff, supra note 96.

158 See Yip \& Khalid, supra note 86.

159 Evelyn Blackwood, "Transnational Sexualities in One Place: Indonesian Readings" in Evelyn Blackwood and Abha Bhaiya, eds, Comparative Feminist Studies: Women's Sexualities and Masculinities in a Globalizing Asia (New York: Palgrave Macmillan, 2007) 181-199.

160 See Yip \& Khalid, supra note 86.

161 See Davies, supra note 11, page 35. 
Many gay Muslims' desire to marry heterosexually is strongly influenced by familial and religious pressures $\left.{ }^{162}\right|^{163}$, and Indonesia is no exception. Meanwhile, 'the family' (traditionally heterosexual) in most societies worldwide becomes a strong opposition to homosexuality, and the rhetoric and values of 'the family' create an unsafe environment for sexual minorities by forcing them to be 'normal' in order to save the family from shame. ${ }^{164}$ The real reason for the objection, though, has to do with gender; the articulation of identities as sexual minorities threatens the assumed naturalness of gender roles and the importance of 'the family' to symbolise the ideal gender practices. $\left.{ }^{165}\right|^{166}$

Magdalene.co's contributors such as The Grand Dark Witch and Sholeh Queer, who identify as sexual minorities, aptly articulate their dilemma of facing marriage as a form of social pressure. It is almost impossible for them to conform without compromising their social identity. The contributors' lived experiences also consist of the struggle with the fear of not obtaining acceptance from their family and bringing shame into the kinship for identifying as sexual minority. This struggle also includes the desire to have a family of their own.

Religion-inspired prejudices against sexual minorities are seldom religious at all in substance; too often the prejudice is inherently political and inexorably linked to affirming power. The power obtained allows the ability to discipline believers and marginalise those who do not religiously conform or aspire to challenge established religious authorities. ${ }^{167}$

In Indonesia, the means to preserve religious-based heteronormative oppression for sexual minorities include instilling fear of judgment for living in sin and instilling shame for not conforming into a heteronormatively religious way of life. Not only do sexual minorities have to face oppression due to their sexual identity while attempting to seek solace in religion, they also must endure the heteronormative double standards. This is an inevitable consequence of living in a society where the call for equality has largely gone unrequited. ${ }^{168}$

\title{
IV. REPRESENTATION OF IDENTITIES IN THE MEDIA AS A FORM OF RESISTANCE
}

\author{
1. Resisting the Heteronormative Double-Standards for Sexual Minorities \\ in Mainstream Media Discourse
}

\footnotetext{
162 Ismail Baba, "Gay and lesbian couples in Malaysia", in Journal of Homosexuality (40(3-4), 2001) 143-163.

163 See Boellstorff, supra note 96.

164 See Baird, supra note 83, page 20, 88-89.

165 Ibid.

166 See Robinson, supra note 130, page 27.

167 See Baird, supra note 83, page 111.

168 See Arnez, supra note 140.
} 
Concluded from the articles analysed in this study, heteronormative doublestandards create problems that uniquely affect sexual minorities in Indonesia. These problems are ingrained in mainstream media discourse where clichés and stereotypes for sexual minorities are categorised into one homogenous group. These cliches and stereotypes are widely publicised and discussed online, fuelled by sexual panics, in just several clicks away. Additonally concluded is the demonization of sexual minorities as folk devils through sex panic scripts in the media as a form of social antagonism, which, as Herdt ${ }^{169}$ notes, is a way of "othering" that revokes their rights as citizens and exposes those who are othered to violence. Therefore, it is important to articulate the resistance against social antoganims by accommodating sexual minorities in the representation of their own identities.

Amid deep-rooted heteronormativity in mainstream media discourse in Indonesia, where coverage of sexual minorities can be supportive while also stigmatising, sensationalising, or condemning ${ }^{170}$, it is quite challenging for sexual minorities to represent themselves and attempt to promote gender and sexual diversity. Such challenges can particularly be observed in the articles by Paramita Mohamad $^{171}$ (2014), Downtown Boy ${ }^{172}$ (2014), The Grand Dark Witch ${ }^{173}$ (2016) and Mario Rustan ${ }^{174}$ (2016).

The first three opinion articles provide a unique take on heteronormative double-standards from the perspectives of a lesbian woman, a gay man, and a transgender woman respectively, which becomes a means to resist social antagonism against sexual minorities. They emphasise the importance of acknowledging equality and diversity through incorporating sexual minorities and the multitudes of their identities into the mainstream media discourse in Indonesia.

Mohamad confronts several lesbian clichés that have evolved around the importance of (heterosexual) men's intervention in the lives of lesbian women, such as them being perpetrators of sexual abuse, an object of hatred, or the chance of having them as the "right" partner. The other authors present a view of resistance against the common belief that a gay, Muslim man should discard one of the aforementioned identities to embrace the other. Also presented is the conflicting circumstances for transgender woman to value a family while also experiencing anxiety about bringing shame into her kinship. The desire to raise

169 See Herdt, supra note 3, page 2-3.

170 See UNDP \& USAID, supra note 12, page 40.

171 See Mohamad, supra note 91.

172 See Downtown Boy, supra note 99.

173 The Grand Dark Witch (pseudonym), "Confession of a Trans Woman" Magdalene.co (2 May 2016), online: http://www.magdalene.co/news-780-confession-of-a-trans-woman-.html.

174 See Rustan, supra note 5. 
her own family still plays a significant part in this internal conflict even though her sexuality is different to that of cis women.

Meanwhile, Rustan highlights the troubling presence of sex panic scripts that demonise sexual minorities. Not conforming to heteronormativity, in his analysis, the LGBTQ community is perceived to be sinfully disastrous, contagious, and threatening to the continuity of human procreation. However, as concerning as it may seem to have such an antagonising view against sexual minorities to spread like wildfire, the producers of sex panic scripts are as afraid as the folk devils to whom they aim their attacks. Rustan argues that the conservatives, whose antiLGBTQ voices are among the loudest, feel cornered in the fight in which "supposedly Muslims" and minorities courageously articulate their resistance against religious-conservative's take on sexual minorities.

This brings us to the larger discussion on how sex panic scripts are materialised in the media, especially on an online platform, which is accessible for anyone with internet connection. On online platforms, sex panic scripts are publicised in the form of, among others, click-baiting headlines and online commentaries in general. In his analysis, Rustan ${ }^{175}$ also refutes the view of Republika.co.id, a conservative-religious news outlet which justifies its opposing view of sexual minorities as a matter of humanity and an attempt of battling moral panics. Republika justifies its view by highlighting the opposite: "LGBTQ scare" as a form of sexual panic that is actually initiated by sexual panic scripts published in conservative-religious media publications, and the term "culture war" as a moral panic in a broader sense.

Meanwhile, commentaries can be found virtually anywhere, including on Muslim and Gay: 10 Facts You May Not Know about $U_{s}{ }^{176}$, which has the largest viewing number among the six selected articles: almost sixty-thousand-page views by the completion of this study. Among mostly supportive comments, a commenter by the name Muhammed says that the author has chosen to suffer by being gay and he would not "follow into this trap of Satan." This comment is seconded by another called "frankly" who later encourages the author to "seek Allah's help."

Sex panic scripts published in the media, which demonise sexual minorities as folk devils, play a pivotal role in arousing sexual panic. Therefore, the articulation of resistance against sex panic scripts requires the incorporation of the voice of sexual minorities themselves and attempts of media publications to challenge the mainstream discourse.

\section{The Efforts of Magdalene.Co to Counter the Mainstream Media Discourse That Marginalises Sexual Minorities}

175 See Rustan, supra note 5.

176 See Downtown Boy, supra note 99. 
Since its inception in September 2013, Magdalene.co has proclaimed itself to be "feminist," "unapologetically liberal," and "a slanted guide to women and issues." Their content related to sexual minorities reflect their belief in equality, diversity, pluralism, and inclusiveness. ${ }^{177}$

Magdalene.co's stance shows that media can also offer a potential antidote for the effects of sexual panics by publicising counter-arguments to these scripts. This could be an unpopular move in the eyes of the public, but the website has its own niche which may be the start of wider readership and exposure.

In order to accommodate sexual minorities in the articulation and representation of their own identities, Magdalene.co uses different forms of journalistic works: a news report, opinion columns and articles, and an advice column. Each form incorporates the representation of identities in different ways to answer three different questions: "what happened," "why that happened," and "was what happened good or bad?"; the first two questions are based on factchecking and the latter is based on personal value judgment of the facts. ${ }^{178}$

In its news report ${ }^{179}$, Magdalene.co attempted to answer the question "what happened?" by introducing the context of the recent LGBTQ controversy in Indonesia. The context is followed by an interview with Firmansyah, a co-founder and treasurer of SGRC UI and the Owner Representative for LGBTQ Support Group Network. As Firmansyah did not identify himself as a sexual minority, he did not speak based on his personal lived experience. Instead, Firmansyah highlighted the challenges for sexual minorities to get the support they need for the oppression and violence they endure because of their sexual identity. In this way, he justifies the need and the urgency to establish a support group for sexual minorities, which had later been widely opposed since its launch.

The incorporation of Firmansyah's statement on sexual minorities challenges the mainstream ideas of anti-LGBTQ in the media, as sexual minorities are seen as a folk devil. ${ }^{180}$ This stance extends to Magdalene.co by the mentioning of the publication as a past media partner for some of SGRC UI's other events and campaigns on various gender and sexuality issues.

Four opinion pieces analysed in this study attempt to answer the question "why that happened," and "was what happened good or bad?"

Magdalene.co's columnist, Mario Rustan ${ }^{181}$ (2016), weaves the identities of sexual minorities in a more nuanced perspective to answer both questions.

In the discourse of anti-LGBTQ in the media, sexual minorities are seen primarily through the conservative-religious perspective as a "foreign," "sinful" peril that should not be tolerated unless the society wants to risk the wrath of God.

177 See Asmarani, supra note 15.

178 David Lauter, “Analysis on the news pages" LATimes.com (13 August 2011), online: http://articles.latimes.com/2011/aug/13/opinion/la-le-postscript-debt-ceiling-news-an20110813.

179 See Nurvitasari, supra note 6.

180 See Herdt, supra note 3, page 5.

181 See Rustan, supra note 5. 
However, Rustan argues that gay men are the only part of sexual minorities of whom people seems to be afraid. Gay men are made the ultimate folk devil, a threat to the institution of family due to their non-heteronormative way of reproduction. This is done at the cost of largely eliminating lesbian women, bisexuals, and transgender people from the conversation.

The other three opinion articles have one thing in common: they are all written by contributors who identify as sexual minorities. These articles provide the largest space for representation of identities by contributors with lived experience as sexual minorities, in this way they can speak for themselves. In addition, the provided space is also pseudonym-friendly, which is an accommodating gesture to welcome sexual minorities in an online haven to discuss their offline, lived experience.

Speaking from her lived experience as a lesbian, Mohamad ${ }^{182}$ challenges a list of lesbian clichés published on web magazine Jezebel.com, arguing that "the whole point of LGBT equality movement is about celebrating diversity." Her public resistance in the media allows her, as a woman who has been openly lesbian half her life, to trace the relatable idea of being a lesbian cliché to the problematic stereotypes of lesbian and how (heterosexual) men play a part in it. She argues that lesbians do not conform to a particular set of rules and regulations to behave as and be one.

Under the pseudonym Downtown Boy (2014), the author of Muslim and Gay: 10 Facts You May Not Know about $U_{S}^{183}$ reveals that the identity of a gay, Muslim man has many intricate layers. Being a gay man and a practicing Muslim (albeit engaging in religiously illicit sexual activities with people of the same sex) may seem "oxymoronic" and "conflicting" and not without constant struggle because "the guilt stays." Still, Downtown Boy believes that the layers can co-exist in order to accept himself the way he is: by embracing his sexuality, keeping his Islamic values, and not forgoing one for the other.

Because Downtown Boy identifies himself as a "semi-closeted," gay man, who wears different masks as to not sacrifice his identities in order to survive the heteronormative double standards, he manages to introduce other kinds of representation of identities of gay men based on his empirical observation; there are gay men who try to appear straight through acting homophobic, living a completely closeted life in a heterosexual relationship with a partner who is completely oblivious of the man's actual sexual orientation all while publicly displaying their religiosity.

In Confession of a Trans Woman, written under the pseudonym The Grand Dark Witch $^{184}$, the author uncovers her anxieties of hurting her family's feelings because she feels that being transgender can be perceived as shameful. Here, her

182 See Mohamad, supra note 91.

183 See Downtown Boy, supra note 99.

184 See The Grand Dark Witch, supra note 173. 
identity is represented as something that may tarnish the family honour if disclosed yet prevent her from fully actualising herself if kept secret.

This way of articulating the lived experiences of a transgender woman is particularly important to challenge the pre-existing tendency to make fun of the effeminate, as it is fairly common to see transgender in the Indonesian entertainment scene playing the role of comic relief. The author poignantly puts it when she highlights that she has feelings just like other human beings and that includes constant guilt for being taught that she is living in sin due to her sexual identity.

Based on these articles, Magdalene.co acknowledges the importance for media publications to represent the identities of sexual minorities as multitudes, whose sexuality intersects with many other parts of their social lives just like other people. This includes not only visible things (such as clothing preference and nongender-conforming appearance) but also clashing values (such as religion and family) and personal feelings (such as fear, shame, guilt, anxiety, and insecurities), all of which stem from the self-identification as sexual minorities. After all, as Downtown Boy points out, sexual minorities just want to make peace with themselves, because "everyone goes through an endless process of selfacceptance."

Meanwhile, two last articles also made mentions of religion or "divine power," from which the authors, as many other members of sexual minorities, seek solace from emotional struggles, rejection, hate, and disgust aimed at them by the heteronormative social judgment. This is in line with the progressive take of Magdalene.co on sexuality and religion, as it has been consistently promoting, among others, reinterpretation of the Quran to see how it aligns with feminism, gender equality, and human rights.

Lastly, in an Ask Madge advice column post titled "Coming Out to Parents," Magdalene.co's editorial team, under the pseudonym of Madge, promotes solidarity from the perspective of a heterosexual ally who is available for a second opinion. This perspective is acknowledged by an advice seeker, who posted under the pseudonym of "Sholeh Queer" (sholeh, from Arabic language, means pious), by addressing the team as "a pro-level fag hag." This piece aims to answer, "was what happened good or bad?" with concerns of future scenarios regarding living an entire lifetime in lies versus the fear of hurting parents because of one's "gayness."

Having heterosexual people answer questions for sexual minorities could be a slippery slope, because the former has been living the heteronormativity-approved life and thus do not have the same relatable, lived experiences of the latter. This is not to say that they could not empathise, as Madge points out in the column, "I can't say whether or not you should come out [...]. But I can tell you that when you're ready [...] it should be in your own terms."

However, it is important to ponder to what extent it is appropriate to publicly give advice from a heterosexual position to sexual minorities. Magdalene.co has 
taken the precautions by adhering to the nature of giving advice, which gives further recommendation for future action to conclude the acts of "assessing, judging, and directing." 185

Moreover, the heterosexual female, "fag hag" Madge occasionally retreats and gives the microphone to Downtown Boy, one of Magdalene.co's regular contributors. Downrown Boy offers a second opinion from his perspective as a gay man. This shows Magdalene.co's attempt not to present Madge as a know-itall ally and advisor, and that she is, at times, willing to share the stage with her BGBF (Best Gay Best Friend).

Another important point is that, on Magdalene.co, contributors are welcome to choose to use their real name or a pseudonym as their by-line, as long as they incorporate a short (2-3 sentences) bio along with it. In this case, the pseudonymity and short bio allow contributors to be at ease with disclosing their identities online while articulating their offline lived experience as sexual minorities. This ability recreates their virtual identity and alternate personae. Bullingham and Vasconcelos ${ }^{186}$ call this act of online pseudonymity as "dividing the self", which highlights certain aspects of one's identities and censors' others leading to 'partial masking'.

In their articles, Magdalene.co's pseudonymous contributors Downtown Boy and The Grand Dark Witch give a hint about their discomfort for thorough public disclosure, which gives a clue about their choice to write under a pseudonym, in which family comes as a common denominator. While in another article (not used in this study), Keeping it Real in the Closet (July 2014), Downtown Boy ${ }^{187}$ admits his fear of causing shock by identifying himself as sexual minority to his closest family members, and The Grand Dark Witch ${ }^{188}$ is concerned about causing shame to her family. Her discomfort for public disclosure also leads to her anxiety to survive each and every day in her 'battlefield', which is being a transgender woman under the scrutinising eyes of the society.

\section{CONCLUSION}

The aim of this research was to discuss the representation of identities of sexual minorities on an Indonesia-based web magazine Magdalene.co through discourse analysis. Representation was investigated based on the notions of hegemony and social antagonism in a sexual panic, in which sexual minorities, who become the

185 Sebastian Hoffmann and Miriam A. Locher, "Constructing the identity of an advice-giver in an American internet advice column" in Text and Talk, vol 26, no. 1, (2006) 67-104.

186 Liam Bullingham and Ana C. Vasconcelos, "The presentation of self in the online world: Goffman and the study of online identities" in Journal of Information Science vol. 39 no. 1 (2013), 101-112.

187 Downtown Boy (pseudonym), "Keeping it Real in the Closet" Magdalene.co (18 July 2014), online: http://magdalene.co/news-205-keeping-it-real-in-the-closet.html.

188 See The Grand Dark Witch, supra note 173. 
scapegoated subject or 'folk devils,' attempt to articulate their lived experience as a means of resistance against their demonization through sex panic scripts in the media.

Throughout this paper, sexual minorities are emphasised as 'The Other' in heteronormative discourses which is inexorably linked to religious perspectives. This is true in relation to the rise of religious conservatism in Indonesia which played a part in fuelling nationwide 'anti-sexual minorities' headlines in early 2016. Although they are mostly rendered invisible and voiceless, the developments of new media introduce the possibility to make themselves visible and articulate their resistance.

This research revealed that religious conservatism is inseparable from heteronormative discourse in Indonesia and, through sex panic scripts, it exaggerates the stigmatisation of sexual minorities as both a danger and a disease $^{189}$ as a sexual panic develops. Such exaggeration can be countered by providing them the opportunity to portray sexual minorities' own, lived experience and represent the multitudes of their own identities. Also, the struggle to resist religious-based heteronormative oppressions is real for sexual minorities in Indonesia. On the other hand, as a new online start-up, with relatively progressive views on gender issues, Magdalene.co has a fairly small and classspecific niche of readership.

Based on the research, there are several points of conclusion. Firstly, not only being made vulnerable by various kinds of oppression due to their sexuality, sexual minorities are also perceived as a threat when religious-morality values in the society are deemed to be compromised as sexual panic ensues. The challenge for heteronormativity begins with the body, the location from which their lived experience as ones with 'unnatural' and 'dangerous' desire takes place and social antagonism justified. Secondly, sexual minorities are often publicly demonised by the media in sexual panics, laden with heteronormativity in conservative-religious perspectives, leaving them little opportunity to speak for themselves and resist; making themselves visible may lead to the negation of their identity. Moreover, sexual panics amplify religious-based, heteronormative oppressions for sexual minorities in Indonesia, from the pressure for heterosexual marriage, the fear for bringing shame to the family for identifying as sexual minority, to the stripping off their rights to practice their religious beliefs. Thirdly, despite all challenges, sexual minorities have the chance to construct their identity through their online persona to resist heteronormative double standards in the media which largely exclude and stigmatize them.

Above all, this research aims to be a reminder that change is inevitable, and no notion is permanent. As heteronormativity is challenged and social antagonism against sexual minorities is resisted so is heteronormative double-standards and

189 Janice M. Irvine, "Transient Feelings: Sex Panics and the Politics of Emotions" in Gilbert Herdt, ed, Moral Panics, Sex Panics (New York: New York University Press, 2009) 235. 
discourses in the media. The ongoing development in new media may continue to create new enablers to articulate the resistance from 'The Other.'

\section{BIBLIOGRAPHY}

Abdelwahab Bouhdiba, (Alan Sheridan, trans.) Sexuality in Islam (Los Angeles: Saqi Books, 1998)Downtown Boy (pseudonym), "Muslim and Gay: 10 Facts You May Not Know About Us" Magdalene.co (16 January 2014) online: http://www.magdalene.co/news-82-muslim-and-gay-\%E2\%80\%93-10-facts-youmay-not-know-about-us.html.

Adrienne Rich "Notes towards a Politics of Location" in Adrienne Rich, Blood, Bread, and Poetry: Selected Prose 1979-1985 (London: Little Brown \& Co, 1984) 210-231.

Andrew K. T. Yip and Amna Khalid, "Looking for Allah: Spiritual Quests of Queer Muslims" in Kath Browne, Sally R. Munt, and Andrew K. T. Yip, Queer Spiritual Spaces: Sexuality and Sacred Places (Farnham: Routledge, 2010)

Anne Fausto-Sterling, Sexing the Body: Gender Politics and the Construction of Sexuality (New York: Basic Books, 2000).

Ayunda Nurvitasari, "SGRC UI Offers Help for LGBT Youth Going Through Hard Time", Magdalene.co (25 January 2016), online:http://www.magdalene.co/news-684-sgrc-ui-offers-help-for-lgbt-youthgoing-through-hard-time.html.

Caroline Ramazanoglu \& Janet Holland, Feminist Methodology: Challenges and Choices (London: SAGE Publications Ltd., 2002)

Chantal Mouffe "Feminism, citizenship and radical democratic politics" in Chantal Mouffe and James Martin, ed, Chantal Mouffe: hegemony, radical democracy, and the political (London: Routledge, 2013)

Chantal Mouffe "Hegemony and New Political Subjects: Towards a new concept of democracy" in James Martin, ed, Chantal Mouffe: Hegemony, radical democracy, and the political New York: Routledge, 2013 (1988))

Christopher Pullen, Gay Identity, New Storytelling and the Media (New York: Palgrave Macmillan, 2009) 
Portraying the Multitudes: Representation of Identities of Sexual Minorities on Indonesia-Based Feminist Web Magazine Magdalene.co

David Lauter, "Analysis on the news pages" LATimes.com (13 August 2011), online: http://articles.latimes.com/2011/aug/13/opinion/la-le-postscript-debtceiling-news-an20110813.

Dennis Altman, Global Sex (Chicago: University of Chicago Press, 2001)

Devi Asmarani, "First Year's a Charm: An Anniversary Note" Magdalene.co (13 November 2014), online: http://magdalene.co/news-278-first-year\%E2\%80\%99s-acharm-an-anniversary-note.html.

Douglas Kellner, Media Culture Cultural Studies, Identity, and Politics Between the Modern and the Postmodern (London and New York: Routledge, 1995)

Downtown Boy (pseudonym), "Keeping it Real in the Closet" Magdalene.co (18 July 2014), online: http://magdalene.co/news-205-keeping-it-real-in-thecloset.html.

Ernesto Laclau and Chantal Mouffe, Hegemony and Socialist Strategy. Towards a Radical Democratic Politics (London: Verso, 1985).

Evelyn Blackwood, "Transnational Sexualities in One Place: Indonesian Readings" in Evelyn Blackwood and Abha Bhaiya, eds, Comparative Feminist Studies: Women's Sexualities and Masculinities in a Globalizing Asia (New York: Palgrave Macmillan, 2007)

Fedina S. Sundaryani, "Commission wants TV, radio free of LGBT" The Jakarta Post (14 February 2016), online: http://www.thejakartapost.com/news/2016/02/14/commission-wants-tv-radio-freelgbt.html.

Gilbert Herdt "Moral Panics, Sexual Rights, and Cultural Anger" in Gilbert Herdt, ed, Moral Panics, Sex Panics (New York: New York University Press, 2009).

Hera Diani, "Religious Resurgence in Indonesia Alarming: Muslim Scholar" Magdalene.co (20 June 2016), online: http://www.magdalene.co/news-843religious-resurgence-in-indonesia-alarming-muslim-scholar.html.

Hermanus J. de Graaf, "South-East Asian Islam to the Eighteenth Century", in P.M. Holt et al., eds, The Cambridge History of Islam Vol. $2 A$ (Cambridge: Cambridge University Press, 1970)

Ian Rivers \& Richard Ward, Out of the Ordinary: Representations of LGBT Lives (Newcastle-upon-Tyne: Cambridge Scholars Publishing, 2012) 
Jacob Torfing, New Theories of Discourse: Laclau, Mouffe, and Zizek (Oxford and Malden: Blackwell, 1999)

Janice M. Irvine, "Transient Feelings: Sex Panics and the Politics of Emotions" in Gilbert, Herdt, ed, Moral Panics, Sex Panics (New York: New York University Press, 2009)

Jason Cromwell, Transmen and FTMs: Identities, Bodies, Genders, and Sexualities (Champaign: University of Illinois Press, 1999)

Katherine Sender (2011) 'No Hard Feelings: Reflexivity and Queer Affect in the New Media Landscape' in Karen Ross, ed., The Handbook of Gender, Sex and Media (Chichester: Wiley-Blackwell, 2011)

Kathryn Robinson, Gender, Islam and Democracy in Indonesia (Abingdon and New York: Routledge/Taylor \& Francis e-library, 2008). See also Robert W. Hefner, Civil Islam: Muslims and Democratization in Indonesia (Princeton: Princeton University Press. 2011)

Khrisna Sen and David T. Hill, eds, Politics and the Media in Twenty-First Century Indonesia: Decade of Democracy (London and New York: Routledge, 2010).

Magdalene "Ask Madge: Coming Out to Parents" Magdalene.co (11 May 2015), online: http://www.magdalene.co/news-384-coming-out-to-parents.html.

"Magdalene, A Slanted Guide to Women and Issues" Magdalene.co (undated), online: http://magdalene.co/static-1-aboutus.html.

Marianne W. Jørgensen \& Louise Phillips, Discourse Analysis as Theory and Method (London, Thousand Oaks, and New Delhi: SAGE Publications Ltd., 2002)

Mario Rustan, 'The LGBT Scare and Indonesia's Culture War", Magdalene.co (7 March 2016), online: http://www.magdalene.co/news-722-the-lgbt-scare-andindonesia $\% \mathrm{E} 2 \% 80 \% 99$ s-culture-war.html.

Martin van Bruinessen, ed, Contemporary Developments in Indonesian Islam: Explaining the "Conservative Turn (Singapore: Institute of Southeast Asian Studies, 2013)

Melissa M. Wilcox, "Outlaws or In-Laws? Queer Theory, LGBT Studies, and Religious Studies" in Karen E. Lovaas, John P. Elia, and Gust A. Yep, eds, LGBT Studies and Queer Theory: New Conflicts, Collaborations, and Contested Terrain (Binghamton: Harrington Park Press, 2013) 
Portraying the Multitudes: Representation of Identities of Sexual Minorities on Indonesia-Based Feminist Web Magazine Magdalene.co

Mia Consalvo, "Gender and New Media" in Bonnie J. Dow and Julia T. Wood, eds, The SAGE Handbook of Gender and Communication (London, Thousand Oaks, and New Delhi: SAGE Publications, Inc., 2006)

Michael Peletz, Gender Pluralism: Southeast Asia since Early Modern Times (New York, NY: Routledge, 2009).

Monika Arnez, "A Dialogue with God? Islam and Lesbian Relationships in Two Post-Suharto Narratives" in Susanne Schröter, ed, Gender and Islam in Southeast Asia: Women's Rights Movements, Religious Resurgence and Local Traditions (Leiden and Boston: Brill, 2013)

Nancy Scheper-Hughes and Margaret M. Lock, "The Mindful Body: A Prolegomenon to Future Work in Medical Anthropology"'in Medical Anthropology Quarterly, New Series, Vol. 1, No. 1, 1987.

Nira Yuval-Davis, The Politics of Belonging: Intersectional Contestations (Los Angeles and London: Sage, 2011)

Paramita Mohamad, "Of Cats and Women: Resisting Lesbian Clichés", Magdalene.co (16 January 2014), online: http://www.magdalene.co/news-80-ofcats-and-women-resisting-the-lesbian-clich\%C3\%A9s.html.

Rachel Rinaldo, Mobilizing Piety: Islam and Feminism in Indonesia (New York: Oxford University Press, 2013)

Robert A. Rhoads, Coming Out in College: The Struggle for a Queer Identity (Westport: Bergin \& Garvey, 1994)

Rusmir Musić, "Queer Visions of Islam" in Samar Habib, ed, Islam and Homosexuality (Westport: Praeger, 2009)

Samar Habib, ed, Islam and Homosexuality (Santa Barbara: Praeger, 2010)

Sebastian Hoffmann and Miriam A. Locher, "Constructing the identity of an advice-giver in an American internet advice column" in Text and Talk, vol 26 , no. $1,(2006)$

Sharyn Graham Davies Gender Diversity in Indonesia: Sexuality, Islam and Queer Selves (Abingdon and New York: Routledge, 2010)

Sharyn Graham Davies \& Linda Rae Bennet "Introduction: mapping sex and sexualities in contemporary Indonesia" in Linda Rae Bennet and Sharyn Graham Davies, eds, Sex and sexualities in contemporary Indonesia (London: Routledge, 2015) 
Puji Maharani

Sharyn Graham Davies, "Surveilling sexuality in Indonesia" in Linda Rae Bennet \& Sharyn Graham Davies, eds, Sex and sexualities in contemporary Indonesia (London: Routledge, 2015)

Stanley Cohen, Folk Devils and Moral Panics: The Creation of the Mods and Rockers (London: MacGibbon \& Kee, 1972)

Susan DiGiacomo, "Metaphor as illness: Postmodern dilemmas in the representation of body, mind and disorder" in Medical Anthropology Volume 14 Issue 1, 1992.

Susanne Schröter, ed, Gender and Islam in Southeast Asia: Women's Rights Movements, Religious Resurgence and Local Traditions (Leiden and Boston: Brill, 2013)

The Grand Dark Witch (pseudonym), "Confession of a Trans Woman" Magdalene.co (2 May 2016), online: http://www.magdalene.co/news-780confession-of-a-trans-woman-.html.

Tom Boellstorff, "Zines and Zones of Desire: Mass-Mediated Love, National Romance, and Sexual Citizenship in Gay Indonesia" in The Journal of Asian Studies (63, no. 2, 2004)

Tom Boellstorff, The Gay Archipelago: Sexuality and Nation in Indonesia (Princeton: Princeton University Press, 2005).

Tom Boellstorff, "Between Religion and Desire: Being Muslim and Gay in Indonesia" in American Anthropologist (107, no. 4, 2005)

UNDP and UNAIDS, Being LGBT in Asia: Indonesia Country Report, Bangkok (2014)

Vanessa Baird, No-Nonsense Guide to Sexual Diversity (Oxford: New Internationalist Publications, 2007)

Yik Koon Teh "Politics and Islam Factors Determining Identity and the Status of Male-to-Female Transsexuals in Malaysia" in Fran Martin \& Peter A. Jackson, eds., AsiaPacifiQueer: Rethinking Genders and Sexualities (Baltimore, US: University of Illinois Press, 2008, pp. 85-98) 
Portraying the Multitudes: Representation of Identities of Sexual Minorities on Indonesia-Based Feminist Web Magazine Magdalene.co

Puji Maharani is an alumna of SOAS, University of London, where she obtained her MA in Gender Studies in 2016. This research, initially written as her dissertation, was also inspired by her undergraduate background in Communication Sciences from Padjadjaran University. She currently works as a development worker. 